\title{
DETERMINANTS OF THE PARTICIPATION OF THE PEOPLE'S REPUBLIC OF CHINA IN THE UNITED NATIONS MISSION IN SOUTH SUDAN
}

\section{INTRODUCTION}

The People's Republic of China's approach to the situation in South Sudan was multidimensional and multifaceted, and contained elements that were opposite. It combined principle with pragmatism, multilateralism with bilateralism, and power politics with mediation (Hodzi, 2017: 4). China's strategy was not coherent, it had many departures and breaches. Beijing wanted to remain flexible and adapt to changing situation, both in South Sudan and on the international stage. On the one hand, it used the rhetoric about non-interference in the internal affairs of states, and on the other, it sometimes went beyond its framework, more strongly pressing on the parties of the conflict to conclude a peace agreement. Anyway, for China, it is very important to preserve the image of a country that respects the diversity of its partners. This is especially important in relation to African states, in which China's interests and influence are growing rapidly.

The purpose of the paper is to analyze and assess the determinants for the participation of the People's Republic of China in the United Nations Mission in South Sudan (UNMISS). The main research question is what were the most important determinants for China's involvement in the UNMISS? The hypothesis of the paper assumes that the main motive for involvement was the protection of China's economic interests in South Sudan and East Africa. China has engaged in South Sudan both to protect oil investments in that country and to prevent the spread of the crisis in the region. By getting involved in UN peacekeeping missions, China also wants to strengthen this organization and create the image of the state responsible for maintaining international peace and security, including the security of African civilians. The Chinese army is also interested in gaining experience in expeditionary operations to increase the ability of military operations in distant theaters. The analysis is conducted in the context of the principle of non-interference in internal affairs. The method of text source analysis was used in the paper. It facilitated the analysis of China's military strategies and UN Security Council resolutions. 


\section{BACKGROUND}

On January 9, 2005, an agreement was concluded in Nairobi to end the civil war between Arab Muslims living in the north of Sudan and black Christians who were the majority in the south. Pursuant to UN Security Council Resolution (UNSCR) 1590 of March 24, 2005, the United Nations Mission in Sudan (UNMIS) was established to operate in the south of the country (United Nationas Security Council, 2005). China was involved in the mission, contributing in 2007435 peacekeepers, including 275-strong engineering division, a 100 -strong transportation division and a 60 -strong medical division (Attree, 2012: 22).

The United Nations Mission in South Sudan is the heir to UNMIS. UNMISS was established pursuant to UNSCR 1996 of July 8, 2011 (United Nationas Security Council, 2011). The mission's goal is to strengthen peace and security in the country, and to help create conditions for development, with particular emphasis on strengthening the capacity of the South Sudanese government to govern effectively and democratically and to establish good relations with its neighbors. Its mandate includes conflict resolution and protection of civilians, as well as support for the government of South Sudan in building the political and economic foundations of statehood (UNMISS...). The mission began operating on July 9, i.e. on the day of independence proclamation by South Sudan. The outbreak of the civil war in South Sudan on December 15, 2013 increased the destabilization of the country and deepened the humanitarian crisis. Therefore, the UNSCR 2132 of December 24, 2013, decided to strengthen the mission (United Nationas Security Council, 2013). The People's Republic of China voted in favor of all these resolutions.

China has also sent one expert to the United Nations Interim Security Force for Abyei (UNISFA) carried out since June 27, 2011 in the border province of South Kordofan between Sudan and South Sudan (Attree, 2012: 22). The border conflict was reviving and other fierce fighting took place in South Kordofan between March and May 2012. The PRC leaders supported UN resolutions calling on parties to end the conflict (Eberling, 2017: 209). Due to international pressure, the conflict formalny ended in September 2012, but tensions between states still existed in 2013.

Greater controversy than in the case of the conflict in the south of Sudan concerned China's attitude towards the long-standing conflict in Darfur, in the western part of the country. Both the West and many African countries expected China to condemn the Sudanese regime for alleged crimes of genocide and to be more involved in resolving the humanitarian crisis (Jia, 2016: 239). After years of obstructive attitude, China finally decided to support and engage in the African Union Mission in Sudan (AMIS), operating since 2004 (Duggan, 2016, 215). After its completion in 2007, under threat of a boycott by the West of the 2008 Summer Olympics in Beijing, Chinese authorities exerted strong pressure on Khartoum to agree to establish the African Union-United Nations Hybrid Operation in Darfur (UNAMID) (Adamczyk, Debita, 2018: 18). China has also sent peacekeeping forces to participate in the mission (Regler, 2016: 236). However, its involvement in UNAMID is much lower than in UNMISS. Besides, China has over the years been accused of breaking the UN 
embargo on arms deliveries to Darfur (more about UN missions in the Sudanese states in: Tlałka, 2020).

\section{THE SPECIFICITY OF CHINESE INVOLVEMENT IN UNMISS}

At the beginning of 2012, China maintained a contingent of 362 soldiers in the UNMISS, mainly engineers, medics and liaison officers, as well as ten experts and six policemen. They were to provide logistical support for humanitarian organizations and medical assistance to refugees and international personnel of the UN. It also included a combat platoon, which was the first unit of this type in the history of the People's Liberation Army (PLA) sent to a peacekeeping mission. Formally, Beijing does not define its forces directed to the UN mission in Africa as "combat units" ("zuozhan budui") describing them as "comprehensive security forces" (Lanteigne, 2016: 16). Beijing emphasizes that they are not parties to the conflicts and their goal is to maintain peace. Initially, however, the role of the platoon stationed in South Sudan was to protect Chinese workers in that country (Cabestan, 2018: 2). It is worth mentioning that in 2013 the Chinese combat unit was also sent to the UN mission in Mali.

On December 15, 2013, civil war broke out in South Sudan. Beijing supported UNSCR 2155 of May 24, 2014. Its purpose was to protect civilians, oil fields and international personnel (United Nations Security Council, 2014). In June 2014, the PRC decided to significantly increase its involvement in UNMISS by sending an infantry battalion of 700 soldiers. The battalion was sent to South Sudan in September 2014. This was the first time in history when China sent such a large combat unit to a peacekeeping mission (Regler, 2016: 237). The battalion was deployed mainly in the states of Unity and Upper Nile, where the Chinese oil infrastructure is located (Bariyo, 2014). However, some Chinese soldiers were also stationed in Juba. In practice, the Chinese contingent focused on the protection of oil installations and workers. Protection of South Sudanese civilians took place mainly within a small radius from oil fields. Participation in the mission was carried out as part of the UN legal system, but in practice it focused on protecting China's overseas interests (Eberling, 2017, 215). Since then, the number of Chinese soldiers serving in UNMISS has remained at just over 1,000 (Nyabiage, 2019).

During the participation in UNMISS, PLA suffered casualties. On July 10, 2016, two Chinese soldiers were killed and five wounded as a result of a missile hitting an armored vehicle. This happened during the protection of the refugee camp near the UN center in Juba. The fighters wanted to break into the camp, so they fired on the forces that protected it. This is worth mentioning that more than a month earlier a Chinese soldier was killed and four were wounded in Mali as a result of an attack by Al-Qaeda fighters. This sparked a discussion in China about the sense and specifics of involvement in UN missions. There have been voices that UN principles limiting the arming of international contingents mean that they are unable to successfully defend against militant attacks (Pinghui, 2016). On July 6, 2018, several dozen fighters armed with rifles attacked the same refugee camp in Juba. Luckily, the negotiations conducted by Chinese soldiers allowed to avoid bloodshed (Huang, 2018). 


\section{POLITICAL, MILITARY, AND STRATEGIC DETERMINANTS OF CHINESE INVOLVEMENT IN UNMISS}

During the Cold War, the authorities of the People's Republic of China were reluctant to the concept of peacekeeping missions. This resulted from attachment to the principles of state sovereignty and non-interference in internal affairs. Beijing recognized peacekeeping missions as interference by Western states motivated by imperialist and neocolonial premises. The initial evolution in this position took place in the 1990s, when China began to direct small military contingents to the UN mission. Until the end of the first decade of the 21 st century, the involvement of the PLA in peacekeeping missions was limited to sending non-combat units performing police, logistics, engineering and medical functions.

Internal and external expectations towards the Chinese authorities regarding the assumption of greater responsibility for international peace and security leads to a further evolution of the approach to peacekeeping missions. The attitude of developing countries which expect to strengthen the role of the UN in maintaining peace is of particular importance. Creating itself as the leader of developing countries, the PRC cannot remain indifferent to this voice (Harnisch, 2016: 45). In recent years, the Chinese government has been more flexible in its approach to non-interference in internal affairs. Since peacekeeping missions require the consent of the host countries, there is no formal violation of state sovereignty. On the other hand, sometimes such consent is forced.

While the issue of participation in UN peacekeeping missions has evolved considerably, there is still reluctance towards humanitarian interventions implemented under the concept of "Responsibility to Protect" (R2P). The undemocratic government in Beijing is skeptical about preventing mass violations of human rights by using military power. It is afraid that such military interference may lead to change of the political regimes. These concerns are justified, as confirmed by the NATO humanitarian intervention in Libya in 2011.

Beijing officially argues that China's support for UN peacekeeping missions is motivated by three main reasons: the strengthening of the United Nations and multilateralism in the world; increasing China's responsibility for international security; and sharing concerns about international peace and security (Yin, 2019). Chinese authorities actually see the UN as the organization that should have the greatest impact on maintaining international peace and security. China wants the military missions not to be carried out independently by the West, but to be the result of a multilateral consensus. Therefore, it wants to strengthen the role and importance of the UN in the global security system. Due to the increasing power, the PRC wants to occupy an important place in this system. China wants to have a real impact on key international security decisions, and be seen as a responsible country contributing to the international peace.

As the power of the PRC increases, its interests in various parts of the world grow. China wants to gain a dominant position in its close vicinity, including in the surrounding seas. China's aspirations do not, however, cover only the immediate neighborhood. It is an important player in strategic competition for key geopolitical regions. In the 
East China Sea and the South China Sea, China is embroiled in a number of border disputes. It also wants to break the buffer created by the United States and its regional allies and partners in the region. In turn, in the Indian Ocean China has been creating so-called "String of Pearls," which is the network of military and commercial facilities along sea lines from Chinese mainland to Port Sudan. One of China's goals in the Indian Ocean is competition with the Indian and American fleets for a dominant position. A symptomatic manifestation of China's military strength projection at a great territorial distance was the construction of the first naval base outside of China - in Djibouti in Eastern Africa. Further locations for this type of installation are currently under consideration, including on the Pakistani coast. China's growing military activity and assertiveness is one of the reasons for its involvement in UN peacekeeping missions. This is to convince the world that the rise of China's power, especially in the military dimension, is to serve peaceful purposes, and not, as perceived by many observers, pose another threat to global peace and security.

Increasing global military activity requires gaining experience in the implementation of various types of missions in a large territorial distance. Engagement in peacekeeping missions in Africa, including the mission in South Sudan, creates great training opportunities for the soldiers of PLA. They operate in a remote area, different in socio-cultural terms and often in war conditions. This activity allows the Chinese army to check logistics capabilities, including the strategic transport. In addition, it teaches soldiers to perform various kinetic and non-kinetic tasks. These missions also enable gaining experience in cooperation with local population and security forces as well as foreign military contingents. Collecting this type of experience is necessary in the process of improving the PLA's expeditionary capabilities and increasing the scale of this type of activity.

At the end of September 2015, President Xi Jinping promised to set up a permanent peacekeeping police squad and to post 8,000 soldiers to a United Nations peacekeeping standby force. In September 2017, these forces were registered in the United Nations. The Chinese leader has also announced the transfer of the USD 100 million to the African Union (AU) to create an African standby force and to boost its capacity for crisis response (Martina, Brunnstrom, 2015). In recent years, China ranked second after the United States in terms of financial contributions to the budget of UN peacekeeping missions. In 2018, it accounted for $10.28 \%$ and in 2019 for $15.22 \%$ of the USD 7 billion budget (Yin, 2019).

In May 2015, 14,735 staff were involved in UNMISS, of which 1,057 from China, which accounted for $7.17 \%$. At that time, the PRC was also involved in the United Nations missions in Mali (402 out of 11,616, which constituted 3.46\%), Liberia (725 out of 7,298, which constituted 9.93\%) and in Lebanon (415 out of 11,330, which constituted $3.66 \%$ ). The PLA also contributed contingents of over two hundred to UN missions in DR Congo (233) and in Sudan (231). The symbolic presence of Chinese representatives was also in missions in Western Sahara (10), Ivory Coast (6), Golan Heights (3) and Cyprus (2) (United Nations Peacekeeping, 2015b). At that time, 101,253 people participated in UN peacekeeping missions, of which 3,084 from China, which accounted for $2.95 \%$. This placed the PRC in 9th place among the contributors to the UN mission, after Bangladesh (9,380), Pakistan $(8,797)$, India $(8,102)$, Ethiopia $(7,862)$, 
Rwanda (5,591), Nepal $(5,332)$, Senegal $(3,575)$ and Ghana $(3,156)$ (United Nations Peacekeeping, 2015a).

In January 2020, 16,492 personnel were involved in UNMISS, of which 1,077 from China, which accounted for $6.53 \%$. At that time, the PRC also maintained staff in UN missions in Mali (426 out of 13,858, accounting for 3.07\%), Lebanon (419 out of 10,260, accounting for 4.08\%), Sudan (371 out of 6,445, accounting for 5.76\%) and DR Congo (226 out of 15,102, which was $1.50 \%$ ). In addition, Chinese staff officers, police officers and civilian experts have participated in other UN missions, including in Western Sachar (10), Cyprus (4), Israel (4) and the Central African Republic (2) (United Nations Peacekeeping, 2020c). At that time, 82,863 people participated in UN peacekeeping missions, of which 2,544 from China, which accounted for 3.07\%. This gave China the 10th place among the contributors, after Ethiopia $(6,639)$, Bangladesh (6,413), Rwanda (6,292), Nepal (5,658), India (5,404), Pakistan (4,341), Egypt $(3,113)$, Ghana $(2,774)$ and Indonesia $(2,705)$ (United Nations Peacekeeping, 2020a). It is worth noting that the PRC was the largest force contributor to the UN mission among the permanent members of the UN Security Council. Due to the spreading pandemic coronavirus SARS-CoV-2 causing COVID-19 illness, in the following months of 2020 there was a drastic reduction of the involvement in UN peacekeeping missions. At the end of March 2020, 2,322 international staff served at UNMISS, of which 46 were from the PRC (United Nations Peacekeeping, 2020b).

China's involvement in UNMISS was conditioned by the situation in South Sudan. When South Sudan gained independence, Beijing had to start a skilful diplomatic game to maintain proper relations with both Sudanese states (Lanteigne, 2016: 16). However, serious tensions between Sudan and South Sudan quickly arose, and border clashes took place. This was caused by a dispute over the shape of the border, as well as fees for the use of crude oil transmission infrastructure in Sudan (Eberling, 2017: 208). Beijing offered mediation assistance and sent Special Envoy (Wissenbach, Wang, 2016: 257). In September 2012, the conflict ended, and in March 2013, the parties withdrew their forces from the border area.

In December 2013, a civil war broke out in South Sudan. It was caused by political rivalry between President Salva Kiir Mayardit and Vice President Riek Machar and feuds between the Dinka and Neur tribes they represent. Vice President Machar was dismissed in July 2013, and in response in December 2013 he conducted a failed coup d'état that turned into a civil war between the tribes. In January 2014, Chinese Foreign Minister Wang Yi publicly called on the parties to end military operations (Copper, 2016, 50). The agreement concluded on May 9, 2014 in Addis Ababa did not bring the fighting to an end. In August 2015 another agreement was concluded between the parties. As a consequence, Machar served as vice president for three months in 2016, which allowed for a temporary ceasefire. However, he was dismissed again, which resumed fighting. The next agreement was signed in September 2018 and is currently being implemented. On February 22, 2019, Machar regained the position of vice president in the Revitalized Transitional Government of National Unity. By April 2018 an estimated 190,000 people have been killed and when factors such as population displacement, disruption to health facilities and lack of food are included the death toll of the civil war was at leas 383,000 (Specia, 2018). 


\section{ECONOMIC DETERMINANTS OF CHINESE INVOLVEMENT IN UNMISS}

In recent years, Africa has become particularly important in the economic policy of the PRC. Between 2000 and 2019, the value of exports from the PRC to Africa increased from USD 5.1 billion to USD 113.2 billion, and in record 2015 it amounted to USD 155.7 billion. In this period, China's imports from Africa also increased significantly, from USD 4.85 billion in 2000 to USD 95.5 billion in 2019, and in record 2018 it amounted to USD 99.3 billion. In the coming months, the economic crisis caused by the SARS-CoV-2 coronavirus may negatively affect international trade. However, after a periodic decline, the long-term positive trend should return.

The PRC promotes economic cooperation with developing countries under the "South-South" concept. China perceives itself as the historical leader of third world countries and is determined to strengthen cooperation with them. As a rule, it does so while respecting the principles of state sovereignty and non-interference in internal affairs. This implies the acceptance of the political, economic and social systems of all countries. This, in turn, opens the way to cooperation also with authoritarian and totalitarian regimes that violate human rights. China provides multibillion loans to developing countries. Unlike Western states, it does not impose any prerequisites on the rule of law, human rights or financial accountability. The loans granted are to be used for the implementation of infrastructure projects by Chinese enterprises. The loans are secured with natural resources, mainly energy resources. China imports raw materials from these countries and exports industrial goods. In recent years, the formula for cooperation has been called the "Angola Model," due to the first agreements of this type concluded in 2004 between the governments of the PRC and Angola. The model is implemented mainly in sub-Saharan African countries, but also in Asia and South America. Given the significant energy deposits of South Sudan, after the stabilization of the country "Angola Model" could be implemented on a large scale.

The change in Beijing's approach to the participation in UN peacekeeping missions was largely caused by the need to defend its economic interests in conflict-torn states (Harnisch, 2016: 46). According to China's Military Strategy of May 2015, along with the growth of China's economic power "its national security is more vulnerable to international and regional turmoil, terrorism, piracy, serious natural disasters and epidemics, and the security of overseas interests concerning energy and resources, strategic sea lines of communication, as well as institutions, personnel and assets abroad, has become an imminent issue" (The State Council, 2015). China's National Defense in the New Era of July 2019 states that sustaining economic development and protecting overseas economic interests are China's fundamental security goals: "One of the missions of China's armed forces is to effectively protect the security and legitimate rights and interests of overseas Chinese people, organizations and institutions." The PLA does so through international security cooperation, including involvement in peacekeeping missions. China wants to strengthen this cooperation primarily in areas closely related to its overseas interests (The State Council, 2019).

Africa is one of the key regions in the implementation of the flagship economic undertaking of President Xi Jinping's administration - "One Belt, One Road" (OBOR). 
The creation of communication links between the PRC and Africa is to facilitate China's access to African deposits of energy resources and markets. The project is also intended to help China beat its competitors, including the United States, the European Union, India and Japan (Bodetti, 2019). China is concerned that the conflict in South Sudan may spread in East Africa, especially to Ethiopia, Kenya and Uganda, in which China implements large infrastructure investments (Hodzi, 2017: 3).

Economic relations between China and South Sudan are characterized by large asymmetry. The investments and development assistance from the PRC play a key role for South Sudan. China, on the other hand, has no important economic interests in that African country yet. As mentioned, however, after the stabilization of security, these interests may increase, and South Sudan could become an important supplier of energy resources to the Middle Kingdom (Wani, 2018). This, in turn, could translate into the rapid construction of state infrastructure by Chinese enterprises and further strengthening of economic relations based on mutual benefits. However, China would have to mitigate conflicts with local communities, including those related to the alleged land grabbing and environmental devastation.

The investments of Chinese oil companies in Sudan date back to 1995. The country's share in Chinese oil imports was 6.5\% in 2007 and 5.3\% in 2010 (Zweig, 2016: 21). After the split of the country, Sudan accounted for up to $2 \%$ of Chinese oil imports, and South Sudan for about 1\% (Wu, Zhang, 2017: 5). In the first decade of the existence of South Sudan, crude oil and its derivatives had invariably around $99 \%$ share in its trade with the PRC (Eberling, 2017: 210).

After the independence, South Sudan took over $75 \%$ of Sudan's oil fields. The new state became the owner of the third largest oil deposits in sub-Saharan Africa, after Nigeria and Angola. However, its transmission was a problem, as the pipeline infrastructure was mostly located in Sudan (Regler, 2016: 237). In January 2012, due to the conflict between the Sudanese states over the transit fees and the shape of the border, South Sudan suspended oil production for fourteen months (Zweig, 2016: 21). This was in China's interest to end the conflict as soon as possible in order to fully benefit from the import of oil from both Sudanese states. For this reason, Beijing exerted diplomatic pressure on the parties of the conflict, which led to its termination in September 2012. However, production and transit of South Sudanese oil did not start until spring 2013 (Eberling, 2017: 208).

The civil war that broke out in December 2013 led to a reduction in Chinese oil imports from South Sudan. Due to the periodically increasing political violence and ethnic conflicts, the level of oil imports from South Sudan has fluctuated significantly in recent years (Hess, Aidoo: 119). The conflict seriously harmed the interests of Chinese companies involved in the South Sudanese oil market, including the China National Petroleum Corporation (CNPC). Instability inhibited extraction, threatened the oil infrastructure and put the life of oilfield personnel at risk. In December 2013, CNPC had to temporarily close oil fields in the Unity and the Upper Nile states because they were in the area controlled by Machar rebels. Chinese oil installations located there have been repeatedly attacked. Periodically, CNPC evacuated about $97 \%$ of its own personnel to Juba (Bodetti, 2019). After a temporary suspension of work, oil production in the oil fields resumed (Wenting, 2019). However, Chinese workers were victims of attacks, and some of them died (Ali, 2018: 117). The most tragic event took place on 
October 19, 2018 in Juba, when 14 Chinese employees of a local oil company were killed as a result of a clash between Dinka and Nuer forces (Jatmika, 2018).

Due to political and military conflicts and high corruption, Western oil companies were afraid to enter the Sudanese and later South Sudanese oil market. Those barriers, however, did not scare Chinese state-owned enterprises, which build their global position also through high-risk investments in destabilized countries (Bodetti, 2019). For this reason, Chinese oil companies control most of South Sudan's oil reserves. CNPC owns $41 \%$ of the largest South Sudanese oil consortia - Dar Petroleum Operating Company (DPOC) and the Greater Nile Petroleum Operating Company (GNPOC). In addition, Sinopec holds a $6 \%$ stake in DPOC (Nyabiage, 2019). After the creation of South Sudan, however, there were no new Chinese investments in the oil sector, which was caused by the fragility of the new state (Johanson, 2016: 187). China had to protect previously initiated oil projects, infrastructure and personnel. Beijing strongly pressed the government in Juba to protect their oil fields in Unity and Upper Nile, which brought measurable results. The South Sudanese government declared its readiness to take "forceful measures" to preserve the security of Chinese investments (Hodzi, 2017: 3-4). Furthermore, China increased the number of its own military contingent in UNMISS, sending soldiers to the oil fields.

Traditionally, China has been very restrained in imposing economic sanctions on countries violating international peace and security, which also concidered South Sudan (Shichor, 2017: 118). In May 2012, it decided to back UNSCR 2046 threatening to impose economic sanctions on Sudan and South Sudan (United Nations Security Council, 2012a). However, this was to be only a form of pressure on the governments of Sudanese states to conclude a peace agreement. When Western countries began to impose economic sanctions on those states, Beijing criticized these actions, considering them detrimental to the peace process. It has maintained economic relations with Sudanese states and has been buying oil from them (Gaudreau, 2016: 220). When Western countries imposed economic sanctions on the political and military leaders responsible for the civil war in South Sudan, China again did not decide on such steps. The withdrawal of companies from other countries caused that China strengthened its dominant position on the South Sudan oil market (Nyabiage, 2019). Beijing, however, supported peace negotiations between the parties of the conflict using various forms of diplomatic pressure. It has argued that after the end of the war and stabilizing security, chinese companies will join the process of rebuilding the country, which will benefit all Southern Sudans (Nyabiage, 2019).

Beijing's foreign and security policy is increasingly opportunistic. China adapts to the situation and sometimes shows less attachment to the traditional principles of this policy. Beijing's strategy is not coherent and usually has several parallel options. In the case of South Sudan, the principle of non-interference in internal affairs was somewhat softened and constituted only a diplomatic camouflage. China has emphasized this principle mostly for propaganda purposes, because for many of its African partners it is crucial. In practice, however, China pressed the parties of the conflic to protect its oil installations and also sent soldiers to a peacekeeping mission with this purpose. On 
the one hand, Beijing was reluctant to engage more seriously in peace negotiations (Hodzi, 2017: 2).

China's involvement in the peacekeeping mission in South Sudan was conditioned by both economic, and political, military and strategic factors. Primarily, the PRC wanted to protect its investments in South Sudan. It was in China's interest to end the conflict to increase its economic involvement in that country. The scope, however, was broader, because Beijing was afraid that the war in South Sudan could destabilize the security of entire East Africa. This would hinder the strengthening of the Chinese regional economic position and the implementation of large investments, including within OBOR. China has also tried to create the image of a country responsible for international peace and security, and sensitive to the fate of Africans. Focusing during the mission on protecting own business ventures, however, showed that in practice these matters were secondary to China.

The engagement it the peacekeeping mission in South Sudan, same like the peacekeeping mission in Mali, gives the Chinese army the opportunity to gain experience in combat environment and learn the specifics of operation in a geographically, climatically and culturally different area. Chinese soldiers can gain experience in the implementation of combat and non-combat tasks as well as cooperation with the local community and security forces. Chinese participation in peacekeeping missions in Africa also gives it the opportunity to learn about the methods of operation of Western military contingents involved in these missions. Given China's increasing military activity outside its own territory, this experience is extremely valuable to the PLA.

\section{REFERENCES}

Adamczyk M., Debita M. (2018), Zasada nieingerencji w sprawy wewnętrzne innego kraju oraz jej miejsce w polityce zagranicznej Chińskiej Republiki Ludowej, "Studia Orientalne", No. 2 (14).

Ali M. A. (2018), China and The Conflict in South Sudan: Security and Engagement, "Journal of Economic, Administrative and Legal Sciences", Issue (2), Vol. 2.

Attree L. (2012), China and conflict-affected states. Between principle and pragmatism, Saferworld, London.

Bariyo N. (2014), China Deploys Troops in South Sudan to Defend Oil Fields, Workers, "The Wall Street Journal", 09.09.2014, https://www.wsj.com/articles/china-deploys-troops-in-southsudan-to-defend-oil-fields-workers-1410275041 (08.04.2020).

Bodetti A. (2019), How China Came to Dominate South Sudan's Oil, "The Diplomat", 11.02.2019, https://thediplomat.com/2019/02/how-china-came-to-dominate-south-sudans-oil/ (12.08.2020).

Cabestan J.-P. (2018), China's Evolving Role as a UN Peacekeeper in Mali, Special Report of the United States Institute of Peace, September, USIP, Washington, https://www.usip.org/ sites/default/files/2018-09/sr432-chinas-evolving-role-as-a-un-peacekeeper-in-mali.pdf (05.04.2020).

Copper J. F. (2016), China's Foreign Aid and Investment Diplomacy. Volume III. Strategy Beyond Asia and Challenges to the United States and the International Order, Palgrave Macmillan, London-New York. 
Duggan N. (2016), China's changing role in its all-weather friendship with Africa, in: China's International Roles Challenging or supporting international order?, (eds.) S. Harnisch, S. Bersick, J.-C. Gottwald, Routledge, London-New York.

Eberling G. G. (2017), China's Bilateral Relations with Its Principal Oil Suppliers, Lexington Books, London.

Gaudreau M. (2016), Plurality in China's South-South Cooperation: The Case of Rice Projects in Mali, in: Facing China as a New Global Superpower Domestic and International Dynamics from a Multidisciplinary Angle, (eds.) H. Cao, J. Paltiel, Springer, Singapore.

Harnish S. (2016), Role theory and the study of Chinese foreign policy, in: China's International Roles Challenging or supporting international order?, (eds.) S. Harnisch, S. Bersick, J.-C. Gottwald, Routledge, London-New York.

Hess S., Aidoo R. (2015), Charting the Roots of Anti-Chinese Populism in Africa, Springer, New York.

Hodzi O. (2017), Strategy of 'Parallels': China in the South Sudanese armed conflict, Asia Centre, Paris, https://centreasia.eu/en/strategy-of-parallels-china-in-the-south-sudanese-armed-conflict-2/ (05.04.2020).

Huang K. (2018), Chinese peacekeepers in tense stand-off with armed militants in South Sudan, 06.01.2018, https://www.scmp.com/news/china/diplomacy-defence/article/2127140/chinese-peacekeepers-tense-stand-armed-militants-south (08.04.2020).

Jatmika A. (2018), 14 Chinese Workers Killed in South Sudan, 19.10.2018, https://en.tempo.co/ $\mathrm{read} / 539251 / 14$-chinese-workers-killed-in-south-sudan (12.04.2020).

Jia Q. (2016), Obama's Election: Its Implications for Sino-American Relations, in: Sino-American Relations. Challenges Ahead, (ed.) Y. Hao, Routledge, London-New York.

Johanson D. (2016), China's Soft Power in Sudan: Increasing Activity but How Effective?, in: China's Media and Soft Power in Africa Promotion and Perceptions, (eds.) X. Zhang, H. Wasserman, W. Mano, Palgrave Macmillan, London-New York.

Lanteigne M. (2016), Chinese Foreign Policy. An introduction. Third edition, Routledge, LondonNew York.

Martina M., Brunnstrom D. (2015), China's Xi says to commit 8,000 troops for U.N. peacekeeping force, "Reuters", 29.09.2015, https://www.reuters.com/article/us-un-assembly-chinaidUSKCNORS1Z120150929 (12.04.2020).

Nyabiage J. (2019), Why China is hoping for a peace dividend in South Sudan, "South China Morning Post", 05.10.2019, https:/www.scmp.com/news/china/diplomacy/article/3031640/whychina-hoping-peace-dividend-south-sudan (08.04.2020).

Pinghui Z. (2016), Two Chinese UN peacekeepers killed, two seriously injured in attack in South Sudan, "Soutch China Morninng Post", 11.07.2016, https://www.scmp.com/news/china/ diplomacy-defence/article/1988348/two-chinese-un-peacekeepers-killed-two-seriously (12.04.2020).

Regler S. (2016), The case of Darfur: diplomacy under influence of Sino-US resource rivalry, in: Sino-US Energy Triangles. Resource diplomacy under hegemony, (eds.) D. Zweig, Y. Hao, Routledge, London-New York.

Shichor Y. (2017), Maximising output while minimising input: change and continuity in China's Middle East policy, w: Chinese Foreign Policy Under Xi, (ed.) H. T. Boon, Routledge, London-New York.

Specia M. (2018), 383,000: Estimated Death Toll in South Sudan's War, "The New York Time", 26.09.2018, https://www.nytimes.com/2018/09/26/world/africa/south-sudan-civil-wardeaths.html (05.04.2020). 
Tlałka K. (2020), Wpływ rozmieszczania operacji pokojowych ONZ na państwa: przypadki Sudanu i Sudanu Poludniowego, Wydawnictwo Adam Marszałek, Toruń.

The State Council (2015), China's Military Strategy, Beijing, http:/english.www.gov.cn/archive/ white_paper/2015/05/27/content_281475115610833.htm (05.04.2020).

The State Council (2019), China's National Defense in the New Era, Beijing, http://english.www. gov.cn/archive/whitepaper/201907/24/content_WS5d3941ddc6d08408f502283d.html (05.04.2020).

United Nations Peacekeeping (2015a), Ranking of Military and Police Contributions to UN Operations (as of 31 May, 2015), https://peacekeeping.un.org/sites/default/files/may15_2.pdf (08.04.2020).

United Nations Peacekeeping (2015b), Troop and Police Contributors (as of 31 May, 2015), www. un.org/en/peacekeeping/resources/statistics/contributors.shtml (08.04.2020).

United Nations Peacekeeping (2020a), Contributors to UN Peacekeeping Operations by Country and Post (as of 31 January, 2020), https://peacekeeping.un.org/sites/default/files/1_summary_of_contributions_20.pdf (08.04.2020).

United Nations Peacekeeping (2020b), Contributors to UN Peacekeeping Operations by Country and Post (as of 31 March, 2020), https://peacekeeping.un.org/en/troop-and-police-contributors (08.04.2020).

United Nations Peacekeeping (2020c), Troop and Police Contributors (as of 31 January 2020), https://peacekeeping.un.org/en/troop-and-police-contributors (08.04.2020).

United Nations Security Council (2005), Resolution 1590 (2005) Adopted by the Security Council at its 5151st meeting, on 24 March 2005, http://unscr.com/en/resolutions/doc/1590 (05.04.2020).

United Nations Security Council (2011), Resolution 1996 (2011) Adopted by the Security Council at its 6576th meeting, on 8 July 2011, http://unscr.com/en/resolutions/doc/1996 (05.04.2020).

United Nationas Security Council (2013), Resolution 2132 (2013) Adopted by the Security Council at its 7091st meeting, on 24 December 2013, http://unscr.com/en/resolutions/doc/2132 (05.04.2020).

United Nations Security Council (2014), Resolution 2155 (2014) Adopted by the Security Council at its 7182nd meeting, on 27 May 2014, http://unscr.com/en/resolutions/doc/2155 (05.04.2020).

UNMISS. Misja Narodów Zjednoczonych w Republice Sudanu Poludniowego, http://www.unic. un.org.pl/misje_pokojowe/unmiss.php (08.04.2020).

Wani D. C. (2018), China-South Sudan Relations: From Margin to the Spotlight, "Modern Diplomacy", 02.10.2018, https://moderndiplomacy.eu/2018/10/02/china-south-sudan-relations-frommargin-to-the-spotlight/ (08.04.2020).

Wenting M. (2019), Chinese peace: Untold stories on the ground in South Sudan, "China Daily", 06.10.2019, https://global.chinadaily.com.cn/a/201910/06/WS5d99566da310cf3e3556ee1b. html (12.04.2020).

Wissenbach U., Wang Y. (2016), Development Policy: Alternatives, Challenges, and Opportunities, in: China, the European Union, and the International Politics of Global Governance, (eds.) J. Wang, W. Song, Palgrave Macmillan, New York.

Wu F., Zhang H. (2017), Introduction: A rising China and the future of world resources, in: China's Global Quest for Resources. Energy, food and water, (eds.) F. Wu, H. Zhang, Routledge, London-New York.

Yin H. (2019), China takes the lead in UN peacekeeping, "China Daily", 26.09.2019, https://www. chinadaily.com.cn/a/201909/26/WS5d8bfa01a310cf3e3556d7f3.html (12.04.2020). 


\begin{abstract}
The purpose of the paper is to analyze and assess the determinants of the participation of the People's Republic of China in the United Nations Mission in South Sudan. The first part of the paper presents the background of the Chinese army's involvement in the Sudanese states, and the second part shows the specificity of its involvement in UNMISS. The next two parts deal, respectively, with political, military and strategic, and economic determinants of China's involvement in this mission. The research problem is contained in the question what were the most important determinants of China's involvement in the UN Mission in South Sudan? The hypothesis of the paper assumes that the main deterimnant of the involvement was the protection of China's economic interests in South Sudan and East Africa. In addition, by being active in UN peacekeeping missions, China wants to strengthen this organization and create the image of the state responsible for maintaining international peace and security. The Chinese army is also interested in gaining experience in expeditionary mission to increase the ability of military operations in distant theaters. The method of text source analysis was used in the paper.
\end{abstract}

Keywords: People's Republic of China, South Sudan, peacekeeping mission, United Nations

\title{
DETERMINANTY UDZIALU CHIŃSKIEJ REPUBLIKI LUDOWEJ W MISJI NARO- DÓW ZJEDNOCZONYCH W SUDANIE POLUDNIOWYM
}

\section{STRESZCZENIE}

Celem artykułu jest analiza i ocena determinantów udziału Chińskiej Republiki Ludowej w Misji Narodów Zjednoczonych w Sudanie Południowym. Pierwsza część artykułu ukazuje tło zaangażowania chińskiej armii w państwach sudańskich, a druga część specyfikę jej zaangażowania w UNMISS. Dwie kolejne części dotyczą odpowiednio politycznych, militarnych i strategicznych oraz gospodarczych powodów zaangażowania się Chin w tę misję. Problem badawczy zawiera się w pytaniu jakie były najważniejsze determinanty zaangażowania Chin w misję ONZ w Sudanie Południowym? Hipoteza artykułu zakłada, że główną determinantą z angażowania była ochrona interesów gospodarczych Chin w Sudanie Południowym i w Afryce Wschodniej. Ponadto, poprzez aktywność w misjach pokojowych ONZ Chiny chcą wzmacniać tę organizację i kreować wizerunek państwa odpowiedzialnego za utrzymanie międzynarodowego pokoju i bezpieczeństwa. Chińskiej armii zależy również na zdobywaniu doświadczeń w misjach ekspedycyjnych, aby zwiększać zdolność działań militarnych na odległych teatrach. W artykule skorzystano z metody analizy źródeł tekstowych.

Słowa kluczowe: Chińska Republika Ludowa, Sudan Południowy, misja pokojowa, Organizacja Narodów Zjednoczonych 
